\title{
Arthropod community at different altitudes in Gunung Halimun-Salak National Park, Western Java, Indonesia
}

\author{
NOOR FARIKHAH HANEDA ${ }^{1, \boldsymbol{v}}$, IWAN HILWAN ${ }^{2}$, EWI IRFANI ${ }^{3}$ \\ ${ }^{1}$ Department of Silviculture, Faculty of Forestry, Institut Pertanian Bogor. Darmaga Campus, Bogor 16680, West Java, Indonesia \\ Tel./fax.: +62-251-8626806/8626886, `email: nhaneda@yahoo.com \\ ${ }^{2}$ Department of Silviculture, Faculty of Forestry, Institut Pertanian Bogor. Darmaga Campus, Bogor 16680, West Java, Indonesia \\ ${ }^{3}$ Graduate Program in Silviculture Tropica, Faculty of Forestry, Institut Pertanian Bogor. Darmaga Campus, 16680, West Java, Indonesia
}

Manuscript received: 27 March 2019. Revision accepted: 28 May 2019.

\begin{abstract}
Haneda NF, Hilwan I, Irfani E. 2019. Arthropod community at different altitudes in Gunung Halimun-Salak National Park, Western Java, Indonesia. Biodiversitas 20: 1735-1742. Gunung Halimun Salak National Park (GHSNP) stores high biodiversity both from its flora and fauna. Parts of the diversity that have not been widely explored are soil arthropods at different altitudes. The aim of this study was to analyze soil arthropod community and the correlation between the attributes of soil arthropods and the environmental factors. The soil arthropods were collected using pitfall traps, placed in several altitudes, i.e., $500 \mathrm{~m}, 700 \mathrm{~m}, 900 \mathrm{~m}, 1100 \mathrm{~m}, 1300 \mathrm{~m}$, $1500 \mathrm{~m}$, and $1700 \mathrm{~m}$. The attributes of community and environmental parameters were analyzed using Pearson correlation and principal component analysis. The result showed that family Formicidae dominated the soil arthropod community. The diversity of arthropods increased with increasing altitudes. The habitat at the altitudes of $1500 \mathrm{~m}, 1300 \mathrm{~m}$ and $1100 \mathrm{~m}$ had a dense canopy, thick litter and high total $\mathrm{N}$ and organic $\mathrm{C}$. There was positive correlation between the attributes of soil arthropod community and environment variables.
\end{abstract}

Keywords: Altitude, arthropod, community, correlation, diversity

\section{INTRODUCTION}

Gunung Halimun Salak National Park (GHSNP) is one of the national parks that has the largest mountain tropical rainforest ecosystem in Java (GHSNPM-JICA. 2007). This area has high biodiversity both from its flora and fauna. Parts of the fauna in GHSNP are soil arthropods.

The presence of soil arthropods is influenced by abiotic and biotic environmental factors. The abiotic factors include soil chemical and physical properties, air temperature, light intensity and thickness of litter, while one of the biotic factors is composition of vegetation. The air temperature is affected by altitude. According to Whitten et al. (1999), with the increase of $100 \mathrm{~m}$ in altitude, the temperature drops by $0.5-0.6{ }^{0} \mathrm{C}$. Temperature affects the presence of insects directly or indirectly, especially the orientation of insects when looking for food, and causes changes in insect physiology in anticipation of adverse climatic conditions (Gillot 1982). The altitude of a place also affects air humidity and wind, which in turn affect the spread of insects (Capinera 2012).

Insect diversity is generally known to be higher in lower areas (Atmowidi et al. 2001; Jing et al. 2005). Insect diversity is also affected by the composition of vegetation. Until now, the studies on arthropods in various altitudes in Indonesia are still rare. Such a study has been done by Atmowidi et al. (2001), but it was carried out 18 years ago, and there must have been some changes since then. Therefore, other studies should be conducted on the effect of site altitude on the diversity of arthropods. This study aimed to analyze the attributes of soil arthropod community (abundance, diversity, community similarity at seven altitudes) and relationship between the community attributes of soil arthropods and the environmental parameters.

\section{MATERIALS AND METHODS}

\section{Study area}

The study was conducted in Gunung Halimun Salak National Park in seven altitudes. The seven locations are located in several resorts, namely Gunung Koneng Resort (500 m), Cimantaja Resort (700-900 m), Gunung Kencana Resort (1100 m), and Cikaniki Resort (1300-1700 m). Field data collection was carried out from September to December 2017. Identification was carried out in December 2017 to May 2018 at the Forest Entomology Laboratory, Faculty of Forestry, Bogor Agricultural University (IPB), Bogor, Indonesia (Figure 1).

\section{Equipment}

The equipment used in this study consisted of 3 groups, namely field tools, laboratory instruments, and supporting tools. Field equipment consisted of shovels, knives, labels and calico cloth. Laboratory equipment consisted of stereo microscopes, specimen bottles (vials), spray bottles, forceps, petri dishes, soil thermometers, air thermometers, scales, soil tester. Supporting tools were identification books, namely Borror et al. (1996), CSIRO (1991), Goulet and Hubber (1993) and internet literature, stationery, and cameras. 


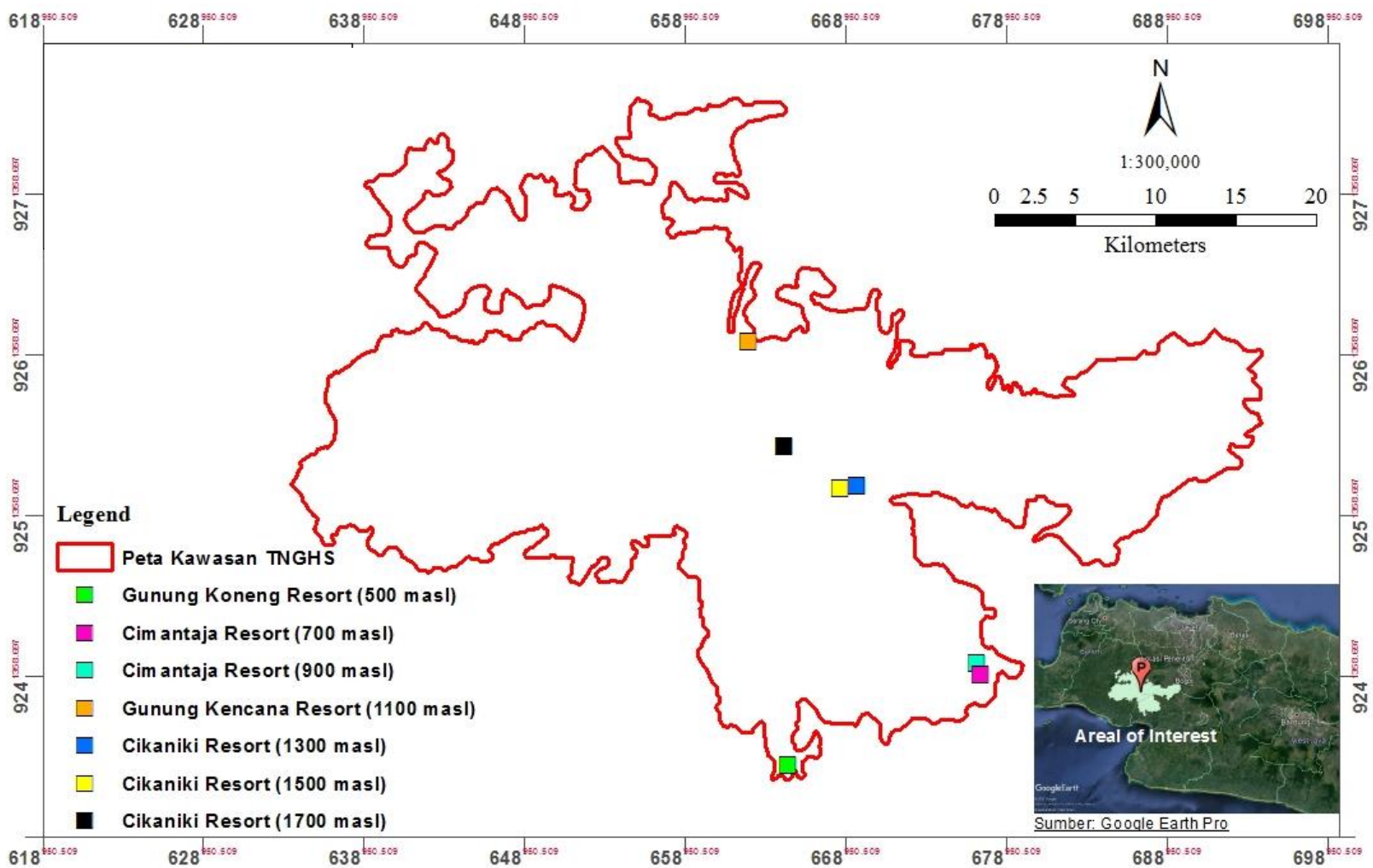

Figure 1. Study sites of Arthropoda study at Gunung Halimun Salak-National Park, western Java, Indonesia

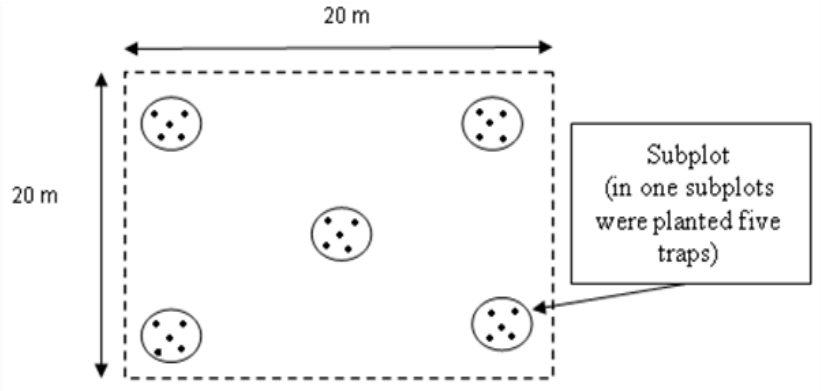

Figure 2. Trap scheme in a plot of $20 \mathrm{~m} 20 \mathrm{~m}$

\section{Procedures}

Sample plots

Sampling of soil arthropods was carried out using pitfall trap method. The sampling was conduected at seven locations with diferent altitudes. In each location, there were five subplots, each subplot having 5 plastic cups installed (Figure 2). So, in one plot there were 25 plastic cups.

The pitfall trap used was a plastic cup with a diameter of $6.5 \mathrm{~cm}$, a base diameter of $4.5 \mathrm{~cm}$ and a height of $10 \mathrm{~cm}$ (Figure 1). Styrofoam with a diameter of $10 \mathrm{~cm}$ with a bamboo stick measuring $13 \mathrm{~cm}$ in length as its support was used as a roof of pitfall trap to prevent rainwater from entering the cup. The installation of a pitfall trap was done by stacking two plastic cups and then inserting them together into the soil, $10 \mathrm{~cm}$ deep. The surface of the ground around the mouth of the cup was leveled, so there was no gap between the cup and the ground, then a plastic cup at the top was taken, to prevent the dirt falling in the pitfall traps. Arthropod collection was carried out for 3 days (Prasifka et al. 2007). To trap the target, the plastic cups were filled with soapy water. Arthropod samples in the pitfall traps were filtered and moved into a $1 / 2 \mathrm{~kg}$ plastic bag and then filled with $95 \%$ alcohol. Plastic bags were tied so that the alcohol did not evaporate, then put in another plastic bag again to avoid leakage that could cause loss of sample. Samples were taken to the laboratory for further processing.

\section{Habitat}

Habitat data collected were vegetation data, air temperature, humidity, soil temperature, thickness of litter, light intensity and chemical properties of soil. The vegetation data taken were the species and number of seedlings, saplings, poles, and trees. Vegetation data were taken in plots, each measuring $20 \mathrm{~m}$ x $20 \mathrm{~m}$ (Kusmana 1997). Data of air temperature and humidity were taken by hanging thermohygrometer then reading the numbers printed after reaching a constant value. Soil temperature was measured by sticking a soil thermometer to approximately $10 \mathrm{~cm}$ depth, then recording the value after it was constant. The recordings of air temperature, humidity, soil temperature were carried out three times, 
namely in the morning (at 07.30 WIB), afternoon (12: 30 WIB), and late afternoon (17: 30 WIB). The thickness of the litter was measured using a ruler, and the value was obtained from the average thickness measurement at three points in 1 plot. Light intensity was measured using lux meter, in four directions in the plot, namely north, south, west and east. For analysis of soil chemical properties, a sample of 500 grams of composite top soil was taken per plot. Each sample of soil was placed in a plastic labeled according to the observation plot. Analysis of soil chemical properties was carried out at the Soil Laboratory of the Department of Soil Sciences and Land Resources, Faculty of Agriculture, Bogor Agricultural University (IPB), Bogor, Indonesia.

\section{Data analyses}

Arthropod community

Shannon-Wiener Diversity Index

$\mathrm{H}^{\prime}=\Sigma \mathrm{Pi} \ln \mathrm{Pi}$

whereas $\mathrm{Pi}=\mathrm{ni} / \mathrm{N}$

Where:

ni: number of individuals of species $i$

$\mathrm{N}$ : number of individuals of all species

Pi: the relative abundance of each species, calculated as the proportion of individuals of the species $i$ to the total number of individuals in the community.

Margalef Diversity Index

$\mathrm{DMg}=(\mathrm{S}-1) / \ln \mathrm{N}$

Where:

DMg: Margalef Species richness Index

$\mathrm{S} \quad$ : Number of species found

$\mathrm{N} \quad$ : Number of individuals for all species

Species evenness index

$\mathrm{E}=\mathrm{H}^{\prime} / \ln (\mathrm{S})$

Where:

E: evenness index

$\mathrm{H}$ ': species diversity

ln: natural logarithm

S: number of species

Simpson dominance index

$\mathrm{D}=\Sigma \mathrm{Pi}^{2}$ whereas $\mathrm{Pi}=\mathrm{ni} / \mathrm{N}$

Where:

ni: the number of individuals of each species

$\mathrm{N}$ : the number of individuals of all species

$\mathrm{D}$ : dominance index

Bray-Curtis similarity index

$\mathrm{C}_{\mathrm{N}}=2 j \mathrm{~N} / \mathrm{Na}+\mathrm{Nb}$
Where:

$\mathrm{CN}$ : Bray-Curtis similarity index

$\mathrm{jN}$ : The lowest number of individuals found in two locations

$\mathrm{Na}$ : The number of individuals at an altitude $\mathrm{A}$

$\mathrm{Nb}$ : The number of individuals at an altitude $\mathrm{B}$

\section{Correlation analysis between the attributes of arthropod} community and the environmental parameters

The correlation between attributes of community and environmental parameters was analyzed using the Pearson correlation test with a confidence level of $95 \%$. Pearson Correlation is a statistical analysis to determine the degree of relationship (in the same direction or inversely) between two or more variables. This correlation is used to analyze whether or not there is a correlation between variables $\mathrm{X}$ and $\mathrm{Y}$, so the magnitude of the variable one's contribution to the other is expressed in percent. The correlation between these variables ( $r$ ) is determined by the formula:

$$
\mathrm{rxy}=\frac{n \sum x y-\left(\sum x\right)(\Sigma y)}{\sqrt{\left(n \sum x^{2}-\left(\sum x\right)^{2}\right\} \sum_{y} 2-\left(\sum y\right.}}
$$

The largest $r$ value is +1 and the smallest $r$ is- $1 . r=+1$ shows a perfect positive relationship, while $r=-1$ shows a perfect negative relationship (Walpole 1995).

\section{Relationship between arthropods and the location of the study}

The correlation between arthropods and the location of the study was analyzed using Principal Component Analysis (PCA) which produced a biplot between component 1 and component 2. Biplot analysis can be used to obtain information related to the relationship between the location of observation of an arthropod morphospecies, and environmental parameters. The accuracy of biplot in explaining the level of diversity of the original data matrix can be formulated as follows (Gabriel 1971).

$$
\rho^{2}=\left(\lambda_{1}+\lambda_{2}\right) / \quad \sum_{k}^{r}=1 \lambda \mathrm{k}
$$

Rencher (2002) argues that the biplot conformity measure can be evaluated by testing two eigenvalues $\lambda 1$ and $\lambda 2$ with the $\mathrm{X}$ matrix approach in two dimensions. If the value of $\rho 2$ is close to one, then the biplot provides a better representation of the actual data information. Sartono et al. (2003) in Mattjik and Sumertajaya (2011) state that there is information that can be obtained from biplot, among others: (i) Proximity of objects: Objects that have the same characteristics will be described by biplot in a position close to each other. (ii) Variety of variables: The variable with the smallest diversity is represented by a short vector and vice versa. (iii) Relations among variables: The relationship between variables is based on the formation angle of the vector of each variable, i.e., Angle $<90^{\circ}=$ Positive correlation, Angle $>90^{\circ}=$ Negative correlation 


\section{RESULTS AND DISCUSSION}

\section{Habitat condition}

Forest habitat at altitudes of 500 to $1700 \mathrm{~m}$ represents a zone of lowland forests, lower mountain or sub-mountain forest (Turer et al 2002; van Steenis 2006). The environmental characteristics of each altitude are different. The average temperature, humidity, soil temperature and light intensity varried among altitudes (Table 1).

Air temperature, soil temperature and light intensity decreased with increasing altitude, while humidity, thickness of litter, soil chemical properties (C-Org and $\mathrm{N}$ Tot) increased. The decrease in light intensity along with increasing altitude was due to the good condition of the forest, so the vegetation density was high and canopy was closed.

\section{Arthropod community \\ Abundance of arthropods}

The abundance of arthropods refers to the number of individual arthropods found at the study site. Generally, the higher the number of arthropod families is, the higher the abundance. The abundance of arthropods at various altitudes can be seen in Table 2 .

The dominant species of Hymenoptera/ant (Formicidae) were found at an altitude of $500 \mathrm{~m}$, namely Pheidole sp. and Polyarchis sp. Many species of Polyarchis sp. were found at an altitude of $500 \mathrm{~m}$, apparently because the sampling location was indeed close to the nest or habitat of this species of ant. According to Andersen (2000), genus Pheidole is generally dominant on the surface of tropical rainforests throughout the world. The abundance of genus Pheidole is likely due to its ability to forage and make nests in cold conditions (Shattuck 2000). At the altitudes of 1100 $\mathrm{m}$ to $1700 \mathrm{~m}$, the dominant species of ant found were Pachycondyla sp, and Myrmecina sp. According to Agosti et al. (2000), Myrmecina is capable of living up to an altitude of $1700 \mathrm{~m}$ with temperature reaching $18^{\circ} \mathrm{C}$ and air humidity reaching $100 \%$. Myrmecina can be found on the ground and under rocks and dead wood. The dominant species in each height habitat can be seen in Figure 3 .

Collembola was the most common and abundant noninsect arthropods at the study site. Of the total arthropods found, $24 \%$ were Collembola. Collembola was found at the altitudes of $1100 \mathrm{~m}$ to $1700 \mathrm{~m}$. The location with the elevation of $1100 \mathrm{~m}$ to $1700 \mathrm{~m}$ has a thicker litter than the altitudes of 500 to $900 \mathrm{~m}$ because of the density of the canopy which is high. According to Suin (1997), temperature is one of the determining factors for Collembola's existence because this group prefers shaded habitat. The lowest number and density of Collembola individuals were found at an altitude of $500 \mathrm{~m}$. The results of the Scherber et al. (2010) showed that the higher the diversity of vegetation is, the higher the diversity of Collembola. The species of Collembola are shown in Figure 4.

\section{Arthropod diversity}

The arthropod diversity in the lowlands was lower than that in the highlands (Table 1). This result was different from that of Atmowidi's (2016) study. It is generally known that insect diversity decreases with increasing altitude.

The diversity and richness of arthropods were high in the sub-mountain zone, at the altitudes of $1100 \mathrm{~m}, 1300 \mathrm{~m}$, and $1500 \mathrm{~m}$. The high diversity of arthropods at an altitude of $1500 \mathrm{~m}$ was supported by the high values of soil organic $\mathrm{C}$ and total N. In addition, high litter thickness was thought to be a factor of high soil arthropods because litter is a food source for soil arthropods.

Table 2. The abundance of the orders of arthropods at several altitudes

\begin{tabular}{|c|c|c|c|c|c|c|c|}
\hline \multirow{2}{*}{ Order } & \multicolumn{7}{|c|}{ Number of individuals at each altitude } \\
\hline & 500 & 700 & 900 & 1100 & 1300 & 1500 & 1700 \\
\hline Akarina & 15 & 20 & 12 & 91 & 30 & 75 & 47 \\
\hline Opiliones & 0 & 1 & 6 & 9 & 12 & 12 & 40 \\
\hline Araneae & 103 & 50 & 102 & 106 & 136 & 107 & 82 \\
\hline Scolopendromorpha & 0 & 0 & 2 & 10 & 6 & 1 & 0 \\
\hline Geophilomorpha & 0 & 0 & 5 & 9 & 6 & 11 & 1 \\
\hline Diplopoda & 2 & 2 & 11 & 21 & 31 & 7 & 11 \\
\hline Isopoda & 1 & 3 & 0 & 13 & 25 & 17 & 23 \\
\hline Amphipoda & 2 & 8 & 3 & 31 & 34 & 17 & 25 \\
\hline Blattaria & 3 & 2 & 8 & 9 & 13 & 3 & 2 \\
\hline Coleoptera & 105 & 84 & 74 & 41 & 107 & 90 & 66 \\
\hline Dermaptera & 10 & 4 & 7 & 6 & 10 & 12 & 25 \\
\hline Diptera & 84 & 129 & 152 & 236 & 154 & 172 & 183 \\
\hline Hemiptera & 3 & 2 & 15 & 4 & 4 & 8 & 1 \\
\hline Hymenoptera & 396 & 363 & 177 & 255 & 234 & 276 & 110 \\
\hline Orthoptera & 44 & 13 & 30 & 47 & 52 & 78 & 41 \\
\hline Thysanoptera & 0 & 1 & 2 & 2 & 3 & 1 & 0 \\
\hline Isoptera & 3 & 1 & 2 & 4 & 12 & 2 & 3 \\
\hline Psocoptera & 1 & 1 & 1 & 5 & 1 & 4 & 0 \\
\hline Lepidoptera & 0 & 1 & 6 & 0 & 3 & 3 & 13 \\
\hline Collembola & 105 & 184 & 104 & 416 & 361 & 300 & 214 \\
\hline
\end{tabular}

Tabel 1. Average measurement of environmental conditions in forest habitats at seven altitudes

\begin{tabular}{|c|c|c|c|c|c|c|c|c|c|}
\hline $\begin{array}{c}\text { Altitude } \\
\text { (m) }\end{array}$ & $\begin{array}{c}\text { Air } \\
\text { temperature } \\
\left({ }^{\circ} \mathrm{C}\right) \\
\end{array}$ & $\underset{\%}{\text { Humidity }}$ & $\begin{array}{c}\text { Soil } \\
\text { temperature } \\
\left({ }^{\circ} \mathrm{C}\right) \\
\end{array}$ & $\begin{array}{c}\text { Litter } \\
\text { thickness } \\
(\mathrm{cm}) \\
\end{array}$ & $\begin{array}{c}\text { Light } \\
\text { intensity } \\
\text { (lux) } \\
\end{array}$ & $\begin{array}{c}\text { C } \\
- \text {-Org }\end{array}$ & $\begin{array}{c}\mathbf{p H} \\
\mathbf{H}_{2} \mathrm{O}\end{array}$ & N-Tot & $\begin{array}{c}\begin{array}{c}\text { Vegetation } \\
\text { density } \\
\text { (ind/ha) }\end{array} \\
\end{array}$ \\
\hline 500 & 25.3 & 73 & 22 & 3.8 & 1236 & 4.5 & 5.64 & 0.41 & 350 \\
\hline 700 & 25.7 & 78 & 21.5 & 4.7 & 1038 & 7.4 & 4.44 & 0.49 & 600 \\
\hline 900 & 25 & 80 & 21 & 5.7 & 1002 & 7.35 & 3.85 & 0.49 & 825 \\
\hline 1100 & 23.3 & 93 & 20 & 7.9 & 532 & 9.13 & 3.65 & 0.6 & 1025 \\
\hline 1300 & 20.1 & 87 & 20 & 7.8 & 600 & 9 & 3.84 & 1.3 & 1100 \\
\hline 1500 & 20 & 84 & 19 & 8.2 & 450 & 10.53 & 3.85 & 1.35 & 1475 \\
\hline 1700 & 18.5 & 97 & 17 & 8 & 901 & 8.61 & 3.61 & 0.64 & 250 \\
\hline
\end{tabular}




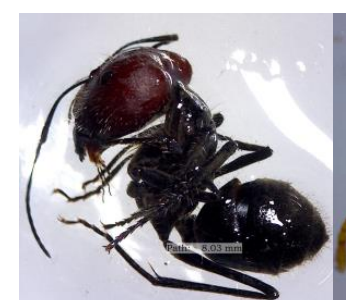

A

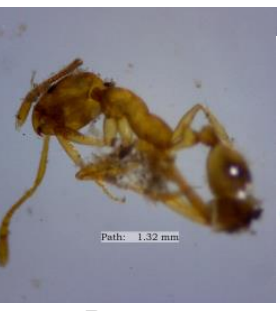

B

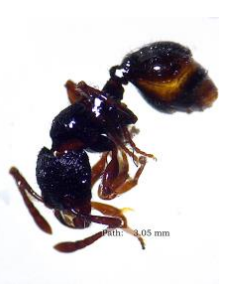

C
Figure 3. A. Dominant species at an altitude of $500 \mathrm{~m}$ Polyrachis sp., B. Dominant at the altitudes of $500 \mathrm{~m}-900 \mathrm{~m}$ Pheidole sp., C. Dominant at the altitudes of $1100 \mathrm{~m}-1700 \mathrm{~m}$ Pachicondyla sp. and Myrmecina sp.

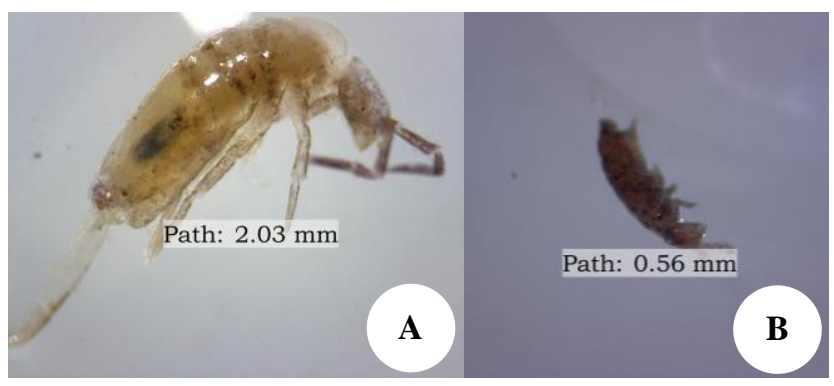

Figure 4. Dominant species of Collembola found were: A. Entomobryidae, and B. Isotomdae

\section{Community similarity index}

The highest similarity index of arthropod community was found between the altitudes of $700 \mathrm{~m}$ and $900 \mathrm{~m}$ (IS = $75 \%$ ) and between $1300 \mathrm{~m}$ and $1500 \mathrm{~m}$ (IS $=75 \%$ ), while the lowest one between $700 \mathrm{~m}$ and $1700 \mathrm{~m}(\mathrm{IS}=31 \%)$ and between $900 \mathrm{~m}$ and $1500 \mathrm{~m}(\mathrm{IS}=40 \%$ ) (Table 4).

\section{Correlation between of arthropod community's attributes and environmental parameters}

Environmental factors have an influence on arthropods. The results of the correlation test using Pearson show the correlation between the attributes of arthropod community with habitat characteristics such as air temperature, air humidity, soil temperature, litter thickness, light intensity, $\mathrm{pH}$, total $\mathrm{N}$, organic $\mathrm{C}$ and vegetation density (Table 5).

\section{Relationship between altitudes of habitats and their characteristics}

Environmental factors have a large influence on the arthropod community, but it is not yet known which environmental factors affect each habitat. In biplot analysis, an eigenvalue of almost $100 \%$ means that biplot provides a good presentation of data information. Based on the results of the biplot analysis, the trend of environmental parameters in each altitude habitat can be seen in Figure 5.

Table 3. Diversity index ( $\left.\mathrm{H}^{\prime}\right)$ and species richness index (Dmg)

\begin{tabular}{lcccccc}
\hline $\begin{array}{c}\text { Altitude } \\
(\mathbf{m})\end{array}$ & $\begin{array}{c}\boldsymbol{\Sigma} \\
\text { orders }\end{array}$ & $\begin{array}{c}\boldsymbol{\Sigma} \\
\text { families }\end{array}$ & $\begin{array}{c}\boldsymbol{\Sigma} \\
\text { Morpho- } \\
\text { species }\end{array}$ & $\mathbf{H}^{\prime}$ & Dmg & $\mathbf{E}$ \\
\hline 500 & 17 & 60 & 77 & 3.45 & 10.704 & 0.794 \\
700 & 20 & 67 & 82 & 3.52 & 12.432 & 0.798 \\
900 & 21 & 83 & 109 & 3.73 & 15.777 & 0.795 \\
1100 & 20 & 84 & 114 & 3.79 & 15.559 & 0.800 \\
1300 & 21 & 92 & 119 & 3.91 & 16.157 & 0.818 \\
1500 & 22 & 98 & 125 & 3.96 & 17.195 & 0.820 \\
1700 & 19 & 53 & 62 & 3.66 & 8.9244 & 0.886 \\
\hline
\end{tabular}

Table 4. The similarity index among arthropod communities at seven altitudes

\begin{tabular}{llllllll}
\hline Altitude (m) & $\mathbf{5 0 0}$ & $\mathbf{7 0 0}$ & $\mathbf{9 0 0}$ & $\mathbf{1 1 0 0}$ & $\mathbf{1 3 0 0}$ & $\mathbf{1 5 0 0}$ & $\mathbf{1 7 0 0}$ \\
\hline 500 & 1 & & & & & & \\
700 & 0.65 & 1 & & & & & \\
900 & 0.59 & 0.75 & 1 & & & & \\
1100 & 0.41 & 0.56 & 0.49 & 1 & & & \\
1300 & 0.52 & 0.59 & 0.43 & 0.69 & 1 & & \\
1500 & 0.58 & 0.51 & 0.40 & 0.64 & 0.75 & 1 & \\
1700 & 0.42 & 0.31 & 0.48 & 0.56 & 0.60 & 0.73 & 1 \\
\hline
\end{tabular}

Table 5. Correlation between environmental parameters and the arthropod community's attributes

\begin{tabular}{lcccccc}
\hline Environmental parameters & $\mathbf{S}$ & $\mathbf{N}$ & $\mathbf{H}^{\prime}$ & $\mathbf{D M g}$ & $\mathbf{E}$ & $\mathbf{D}$ \\
\hline Air temperature $\left({ }^{\circ} \mathrm{C}\right)$ & -0.10 & -0.48 & -0.66 & -0.08 & -0.77 & 0.11 \\
Humidity $(\%)$ & 0.24 & 0.59 & 0.67 & 0.15 & 0.72 & 0.24 \\
Soil temperature $\left({ }^{\circ} \mathrm{C}\right)$ & 0.07 & 0.25 & -0.46 & 0.15 & -0.94 & -0.20 \\
Litter thickness $(\mathrm{cm})$ & 0.88 & 0.89 & 0.79 & 0.28 & 0.70 & 0.21 \\
Light intensity $(\mathrm{Lux})$ & -0.60 & -0.86 & -0.91 & -0.69 & -0.19 & -0.29 \\
pH $(\mathrm{H} 2 \mathrm{O})$ & -0.43 & -0.36 & -0.72 & -0.41 & -0.46 & -0.69 \\
C-Org & 0.59 & 0.84 & 0.87 & 0.56 & 0.40 & 0.48 \\
Total N & 0.65 & 0.65 & 0.85 & 0.60 & 0.21 & -0.11 \\
Vegetation density $\left(\mathrm{ind} / \mathrm{m}^{2}\right)$ & 0.75 & 0.68 & 0.86 & 0.94 & -0.25 & 0.30 \\
\hline
\end{tabular}

Note: $\mathrm{S}=$ number of morphospecies, $\mathrm{N}=$ number of individuals, $\mathrm{H}$ '= species diversity index, $\mathrm{DMg}=$ species richness index, $\mathrm{E}=$ species evenness index, $\mathrm{D}=$ type dominance index. 


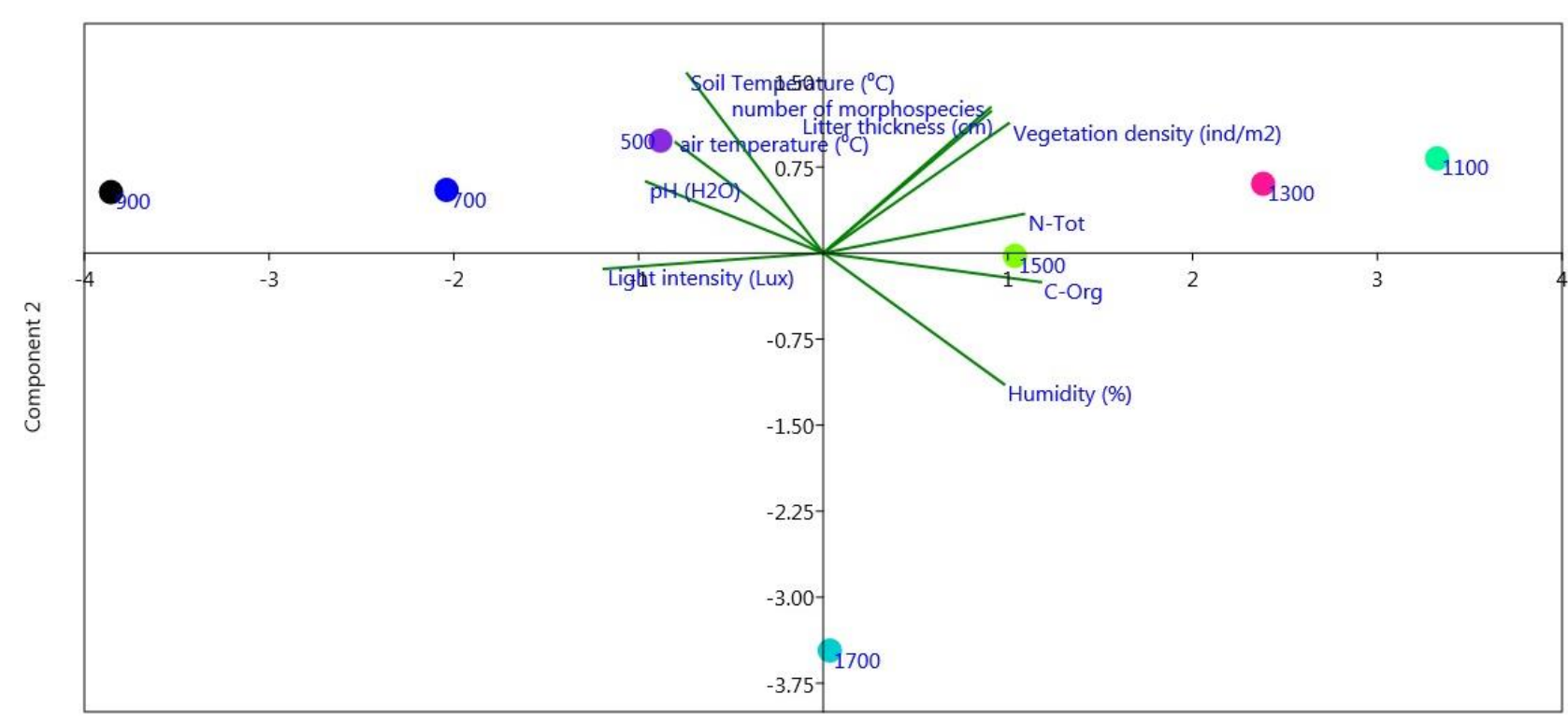

Component 1

Figure 5. The ordination of environmental parameters and altitudes based on Principal Component Analysis

\section{Discussion}

The sampling of the soil surface arthropods used pitfall trap method. Pitfall trap is a method of collecting collections of land-based fauna using containers planted in plots of land (Chick 2016). This method can capture active ground insects above the soil surface both nocturnal and diurnal (Marshall et al. 1994; Greenslade et al. 2000; Santos 2007). Pitfall trap installation aims to trap arthropods so that their abundance can be calculated. Abundance is the total number of individuals found in each plot. Abundance data showed that the site with altitudes of $500 \mathrm{~m}-900 \mathrm{~m}$ had the smallest number of individuals. In the altitudes of $500 \mathrm{~m}$ to $900 \mathrm{~m}$, the habitats experienced disturbances in the form of conversion of forest land into plantation land and fodder collection in the forest. The vegetation in this habitat was composed of durian (Durio zibethinus), clove (Syzygium aromaticum) and coffee (Coffea sp). Meanwhile, the highest abundance was found at an altitude of $1100 \mathrm{~m}$, which is categorized as lower mountain or sub-mountain forest. The characteristics of sub-mountain forests are the presence of various species of epiphytes, lianas, ferns, understory, mossy trees and thick litter cover. The order of Hymenoptera had the highest number of individuals among all orders in all altitudes. The family that dominates the order of Hymenoptera was family Formicidae, an insect that is often found on the surface of the land in both the dry and rainy seasons (Ruslan and Haneda 2007). Table 2 shows that the number of individual of Hymenoptera decreased with increasing altitude. Its highest number was found at an altitude of 500 $\mathrm{m}$, i.e., 396 individuals and the lowest one at an altitude of $1700 \mathrm{~m}$, i.e., 110 individuals. Reduction in the number of individual ants based on altitude occurs in the highlands, whereas in the lowlands there is an increase (Brown 1973). This decrease is evidenced by Araujo and Fernandes (2003) based on the pattern of altitude and habitat variation on Mount Espinhaco Brazil showing a decrease in the number of species from the altitude of 800 meters to 1500 meters. Likewise, Bruhl et al. (1999) reported that the number of species and individuals of leaf litter ants on Mount Kinabalu, Sabah, Malaysia decreased with increasing altitude.

Collembola was the most common and abundant noninsect arthropods at the study site. Of the total Arthropods found, $24 \%$ were Collembola. Collembola can be found throughout forest height habitats and is often found on the surface of the land. Collembola is found in areas that have thick litter because this group is litter eaters. Collembola was found at the altitudes of $1100 \mathrm{~m}$ to $1700 \mathrm{~m}$, which had thicker litter than the altitudes of $500 \mathrm{~m}$ to $900 \mathrm{~m}$, because of the high density of the canopy. The smallest arthropods such as tail springs (Collembola) and mites (akari) are predominantly found in mountainous and arctic regions (Schatz 1981; Solhoy et al. 1975; Ryan 1977; Coulson et al. 1996). According to Suin (1997), temperature is one of the determining factors for the presence of Collembola because this group prefers shaded habitat. The dominant families of Collembola found were Entomobryidae and Isotomidae.

The results of the calculation of arthropod diversity index in GHSNP were different from those of other studies in general. The diversity in the lower land is generally higher than that in the higher land (Atmowidi 2016). Apparently, the disturbances and climate change have resulted in soil insects adjusting to the habitat that supports their development. The highest diversity index was obtained at the altitude of $1500 \mathrm{~m}$, i.e., 3.96, followed by that of $1300 \mathrm{~m}$, i.e., 3.91, that of $1100 \mathrm{~m}$, i.e., 3.79, and the lowest one was at the altitude of $500 \mathrm{~m}$, which was 3.45 . This habitat at the altitudes of $1500 \mathrm{~m}, 1300 \mathrm{~m}$, and $1100 \mathrm{~m}$ 
have a good forest condition, with dense canopy density, thick litter layer and high total $\mathrm{N}$ and organic $\mathrm{C}$. The habitat at an altitude of $500 \mathrm{~m}$ has a low density because it is close to the plantation and gets many disturbances. Apart from that, suspected climate change may also cause habitat adjustment in arthropods. According to Larsson (2014), an increase in carbon raises global temperatures by $1^{\circ} \mathrm{C}$, so the effects of this have already been seen with the missing of many species because they fail to adapt to extreme environments and their habitats have been reduced. Whittaker and Tribe (1996) mention that the abundance of Neophilaenus lineatus has increased in high altitudes from year to year.

The results of the correlation test using Pearson showed that habitat characteristics did not have significant effect on the number of morphospecies. The results of the correlation analysis showed that the soil temperature was negatively correlated with the evenness of arthropod species ( $\mathrm{r}=-$ 0.94). The thickness of litter was positively correlated with the number of morphospecies $(r=0.88)$ and number of individuals $(r=0.89)$. Individual abundance and diversity were negatively correlated with light intensity with $r$ values of-0.86 and-0.91 respectively, but were positively correlated with organic $\mathrm{C}$ and total $\mathrm{N}$ with $\mathrm{r}$ values of 0.84 and 0.87 respectively. The total $\mathrm{N}$ and the density of vegetation were positively correlated with diversity index with $r$ values of 0.85 and 0.86 , and with species richness with $r$ values of 0.60 and 0.94 respectively. According to Hilwan et al. (2013), the presence of mesofauna and macrofauna in soil is highly dependent on the availability of energy and food sources to sustain life, such as organic matter and living biomass which are all related to the flow of carbon cycles in the soil. In this study the correlation between the number of arthropods with temperature was negative: the lower the temperature, the greater the number of arthropods. These results were different from those of other studies which state that the lower the temperature the number of insects or arthropods will decrease. It seems that the reduced number of arthropods at lower altitude is due to climate change and the presence of disturbances, so the insects or arthropods have adapted to the environment that suits them.

At the altitudes of $500 \mathrm{~m}, 700 \mathrm{~m}$ and $900 \mathrm{~m}$, the air temperature, soil temperature, and $\mathrm{pH}$, had the same characteristics. The air temperature, soil temperature, and $\mathrm{pH}$ were higher at an altitude of $500 \mathrm{~m}$. At the altitudes of $1100 \mathrm{~m}, 1300 \mathrm{~m}$, and $1500 \mathrm{~m}$, the total $\mathrm{N}$, organic $\mathrm{C}$ and abundance have the same characteristics, but the vegetation density higher at the altitude of $1500 \mathrm{~m}$.

This study concluded that the attributes of soil arthropod community in GHSNP were correlated with the environmental parameters and the species diversity of soil arthropods was negatively correlated with the temperature.

\section{ACKNOWLEDGEMENTS}

The writers thank the mentors who have guided so far, to the Gunung Halimun Salak National Park who has facilitated the writers in the study. This study can be carried out with the collaboration of the Faculty of Forestry, Bogor Agricultural University (IPB), Bogor, Indonesia with the National Institute Ecology, Korea under the name of the Project namely Long Term Ecological Study.

\section{REFERENCES}

Andersen AN. 2000. Global ecology of rainforest ants: functional groups in relation to environmental stress and disturbance. In: Agosti D, Majer JD, Alonso LE, Schultz TR (eds.). Ants: Standard Methods for Measuring and Monitoring Biodiversity. Volume 3. Smithsonian Institution Press, Washington DC.

Araujo LM, Fernandes GW. 2003. Altitudinal pattern in a tropical ant assemblage and variation in species richness between habitats. Lundiana 4 (2): 103-104.

Atmowidi T, Prawasti TS, Utomo S, Kurniawan Y. 2001. Keanekaragaman diptera (insecta) di Gunung Kendeng dan Gunung Botol, Taman Nasional Gunung Halimun, Jawa Barat. Biodiversitas 6 (5): 773-779.

Brown WL. 1973. A comparison of the Hylean and Congo-West African rain forest ant faunas. In: Meggers BJ, Ayensu ES, Duckworth WD (eds.). Tropical Forest Ecosystem in Africa and South America: a Comparative Review. Smithsonian Institute, Washington DC.

Bruhl CA, Gunsalam G, Linsenmair KE. 1998. Stratification of ants (Hymenoptera, Formicidae) in primary forest on Mount Kinabalu, Sabah Malaysia. Trop Ecol 14: 285-297.

Capinera JL. 2012. Sweetpotato Weevil,Cylas formicarius (Fabricius) (Insecta: Coleoptera: Brentidae (Curculionidae)). https: //edis.ifas.ufl.edu/in154 capinera spw1.

Chick A. 2016. Insect Microscopy. British Library, London.

Coulson SJ, Hodkinson ID, Webb NR, Block W, Bale JS, Strathdee AT, Worland MR, and Wooley C. 1996: Effects of experimental temperature elevation on high-arctic soil microarthropod populations. Polar Biol 16: 147-153.

Gabriel KR. 1971. The biplot graphic display of matrices with application to principal component analysis. J Biometrica 58: 453-467.

GHSNPMP-JICA. 2007. Taman Nasional Gunung Halimun-Salak. Bogor. Email: info@halimun.go.id/mgh (g)/telkom.net.Website: www.tnhalimun.go.id.

Gillot C. 1982. Entomology. University of Saskatchewan, Saskatoon, Canada. Plenum Press.New York and London.

Greenslade P, Deharveng L, Bedos A, Suhardjono YR. 2000. Handbook to Collembola of Indonesia. RCB-LIPI, Cibinong, Bogor.

Hilwan I, Handayani EP. 2013. Keanekaragaman mesofauna dan makrofauna tanah pada areal beka tambang timah di Kanupaten Belitung Provinsi Kepulauan Bangka-Belitung. Silvikultur Tropika 4: 35-41. [Indonesian]

Jing S, Solhoy T, Huifu W, Vollan TI, Rumei X. 2005. Differences in soil arthropod communities along a high altitude gradient at Shergyla mountain, Tibet, China. Arctic Antartic Alpin Stud 2 (37): 261-266.

Kusmana C.1997. Metode Survey Vegetasi. Institut Pertanian Bogor, Bogor Indonesia

Larsson B.2014. Alpin Arthropod Diversity Spatial and Environmental Variation. Department of Biological and Environmental Sciences, University of Gothenburg, Germany.

Magurran AE. 2004. Measuring Biological Diversity. Malden, United States

Marshall SA, Anderson RS, Roughley RE, Pelleter B, Dankis. 1994. Terrestrial arthropod biodiversity: planning a study and recommended sampling techniques. Entomol Soc Can 26: 1-17.

Mattjik AA, Sumertajaya IM. 2011. Sidik Peubah Ganda dengan Menggunakan SAS. IPB Press, Bogor, Indonesia. [Indonesian]

Prasifka JR, Lopez MD, Hellmich RL, Lewis LC, Dively GP. 2007. Comparison of pitfall traps and litter bags for sampling grounddwelling arthropods. J Appl Entomol 131: 115-120.

Rencher AC. 2002. Methods of Multivariate Analysis. 2nd ed. John Willeand Sons Inc., New York.

Ruslan H and Haneda NF. 2007. Fluktuasi Kelimpahan dan Keragaman Serangga Permukaan Tanah di Pinggir Sungai Ciliwung Jakarta. 
Kongres VII dan Seminar Nasional Perhimpunan Entomologi Indonesia (PEI). 25-27 Juli 2007, Bali, Indonesia. [Indonesian]

Ryan JK. 1977: Synthesis of energy flows and population dynamics of Truelove Lowland invertebrates. University of Alberta Press, Edmonton, Alberta.

Schatz H. 1981: Abundance, biomasse und respirtionsrate der arthropoden-mesofauna im hochgebirge (obergurgl, tiroler zentralalpen). Pedobiologia, 22: 52-70.

Santos SAP, Cabanas JE, Pereira JA. 2007. Abudance and diversity of soil arthropods in olive grove ecosystem (Portugal): Effect of pitfall trap type. Eur J Soil Biol 43: 77-83.

Scherber C, Eisenhauer N, Weisser WW, Schmid B, Voigt W, Fischer M, Schulze ED, Roscher C, Weigelt A, Allan E, et al. 2010. Bottom-up effects of plant diversity on multitrophic interactions in a biodiversity experiment. Nature. 468: 553-556.

Shattuck SO. 2000. Australian Ants: Their Biology and Identification. CSIRO Publ., Collingwood, Australia.

Solhoy T, Ostbye E, Kauri H, Lien L, Skar HJ.1975. Faunal structure of Hardangervidda, Norway. In: Wielgolaski FE (ed.). Animals and System Analysis. Ecological Studies 17: 29-45.

Suin MN. 1997. Ekologi Hewan Tanah, Jakarta. [Indonesian]

Walpole RE. 1995. Pengantar Statistik, Jakarta. [Indonesian]

Whittaker J.B, Tribe NP. 1996. An altitudinal transect as an indicator of responses of a spittlebug (Auchenorrhyncha: Cercopidae) to climate change. European J Entomol 93: 319-324.

Whitten T. Soeriaatmadja RE, Afief SA. 1999. Ekologi Jawa dan Bali. Prennhalindo, Jakarta. [Indonesian] 